Logos Universality Mentality Education Novelty, Section: Social Sciences

ISSN: $2284-5747$ (print), ISSN: $2284-5747$

(electronic)

Covered in: CEEOL, Index Copernicus, Ideas

RePeC, EconPapers, Socionet

\title{
THE ROLE OF VIRTUE ETHICS IN THE DEONTOLOGICAL TRAINING OF PROSPECTIVE TEACHERS
}

\author{
Viorica - Torii CACIUC \\ Logos Universality Mentality Education Novelty, Section: \\ Social Sciences, 2014, Year III, Issue 1, pp: 47-56 \\ Published by: \\ Lumen Publishing House \\ On behalf of: \\ Lumen Research Center in Social and Humanistic Sciences
}




\title{
The Role of Virtue Ethics in the Deontological Training of Prospective Teachers
}

\author{
Viorica - Torii CACIUC ${ }^{1}$
}

\begin{abstract}
Today, the topic of insuring the quality in education is brought up often in public, legislative and academic debates. By analysing the new educational politics, we got to the conclusion that among the variables which ensure a quality education, there is the so called "quality of the teachers' work.". This, in its own turn, depends on the quality of the initial and continuous training, on instructional standards, on the evaluation and certification of the didactical skills (Dumitru, 2007, pp. 13 - 23), and even on the deontological values and norms in the spirit of which the training and the teachers' skills improve. The pedagogical language plays a special role in the training of future teachers. Its formative value is given both by its socio-cultural values and its pragmatic ones. Besides all these, there are also the ideological values that reflect the political conception which, at a given moment, dominated the society's educational policy which was applied at the school level. All of these make the true educational message harder to be perceived by the future teachers, and many times it seems to be inadequate for the nowadays school system. So, it looks hard to put it into educational practice. This is the reason why our proposal is to have a deontological training content open towards virtue ethics which could restore the power of the moral values and virtues, the returning to their abstract significance and to the concrete reality they express.
\end{abstract}

Keywords:

Virtue ethics, pedagogical deontology, the quality of education, responsible attitude, deontological values

${ }^{1}$ PhD Lecturer, Teacher Training Department, "Dunărea de Jos" University of Galati, Romania, caciuca@yahoo.com.

CACIUC, V-T. (2014). The Role of Virtue Ethics in the Deontological Training of Prospective Teachers. Logos Universality Mentality Education Novelty, Section: Social Sciemces, Year III, Issue 1, 2014, pp. 47-56 


\section{Introduction}

The current tendencies and orientations in the didactic career have generated changes both at the conceptual and methodological level. To base the didactic career on the National High Education Qualification Framework represents a priority of the present day educational politics. So, "the integrative manner, both under the professional and transversal aspect of the abilities, and the progressivegradual aspect which helps build them, is also applied in the didactic field, the quality of the training programmes reflecting not only the vision and the purposes of the new educational politics, but also the professionalism of the human resource in education" (Marin, 2013, p. 86). In this context, to respect and to develop the values and the professional ethics, which are part of the transversal abilities, should occupy a significant place in the teachers' initial training programmes. The quality of the didactic activity of future teachers depends also on the deontological values and norms, in which's spirit it is accomplished the training and perfecting of teachers.

\subsection{Theoretical perspectives}

As it is already known, deontology has been outlined as a science of the rights and duties which regulate the human activity in a professional field. The term "deontology" (deontos= duty, obligation, and logos= word, science) was used for the first time by the English philosopher Jeremy Bentham in the paper called "Deontology or the Science of Morality" (1834 - apud. Voicu, A.V., Levi, A., 2003), which he defined as being the science of what we should respect. In its evolution, "deontology appeared, in this context, as a professional expression of the fundamental moral commandment to respect the indefeasible attributes of the human being (dignity, freedom, responsibility, the right to pride and to self-esteem, etc.). It seemed natural that the first, and then later most developed deontological codes to belong to some professional fields like: medicine, psychology, pedagogy, sociology, judicial occupations. The deontological norms have become established in these fields with such a strength that today they are, almost totally, part of laws, regulations, statuses and professional codes which, officially or unofficially, have been imposed as rules for the occupational practice" (Voiculescu, 2000, p. 182).

Because teachers are working with turning personalities, their social responsibility is at the height of their noble mission, that of training young, capable people to be actively integrated in the social life through the exertion of a profession, through the usage of some moral values and rules in their behaviour as citizens and members of a community which is in a continuous change. If we take into consideration that the process of training and of developing the young generation is as meticulous, as precise and delicate as the polishing of diamonds, and as a mistake of the jeweller can lead to the loss of the value of the precious gem, the same applies in the case of the teacher. His mistake may contribute to the decrease of the intrinsic value of the young person. In this context, we are dealing, 
as in any other field of activity, with the problem of rejects and with the fact that in the didactic profession it is not allowed and/or it should not be allowed not even the smallest percentage of rejects, a problem which is discussed here in other terms because of the specific of the educational field. In the interwar pedagogical literature, the teachers that were not respecting the deontological norms of their profession were harshly criticized: "the teacher who, out of laziness or pride, gives up, in many cases, with impertinence and by making a lot of noise (at the quality of the pedagogical work - n.n. Voicu, A. V.) - even when the teacher is a political figure or an influential character - he should be considered and treated as a killer of souls, but a premeditated killer, a danger not only for the pupils' soul, but also for the community that has given him the right to teach the new generation." (Voicu, Levi, 2003.)

In the context of increasing the quality of the didactic act, the research of the connection between the causes and the results which are boosting the educational context, the reductionist temptations and the ways of avoiding them, constitute a priority of the educational sciences. The quality of the didactic activity results, most of the time, from the competence with which the didactic staff manages to obtain good results that correspond to their settled goals, as part of organized and intentionally unfolded activities. The efficiency and efficaciousness with which a teacher manages to unify the three major activities of the educational process - teaching, learning, and evaluation - do not reflect only the pedagogical competences and their skilfulness, but also their moral qualities.

Thus some of the moral principles and values are reflected in the style of teaching, in "the personal equation of the teacher", as a sign of subjectivism, from the act of evaluation, in the typology of the relationships he/she has with the pupils, with the parents or with the academic community that he/she belongs to. Alongside the problem of subjectivism in evaluation and its moral connotations, we can see some other aspects which can be directly or indirectly associated with the moral code of the teacher and which's analysis imposes a deontological approach.

The myth and the error of the so called "master" teacher, which in the general pedagogical plan is an expression of the magistro-centrism, in the evaluation plan "is translated as a special gesture of the teacher's 'immovability' or of his/her 'immunity' regarding the marks which he/she gives or the way in which he/she gives them"; we are dealing here with the irreducible right of the teacher to be "the master of his/her discipline" (Voiculescu, 2000, pp. 181 - 182). In this context, the sanction character of the evaluation results on the one hand out of the fact that the marks are given not to a concrete pupil, but to an abstract one, that has the obligation to study, to be obedient and to comply with the evaluation act, and, on the other hand, it is owed to the feelings of obligation and moral responsibility which the teacher feels during the process of evaluation, which overcomes the concrete reality of the pupils. "In certain limits and bearing the school print, the behaviour excesses caused by the power which a teacher has or thinks it has, appear 
frequently in the evaluation act. They are manifesting under the shape of excessive severity, of the final mark which is no more debatable, of the lack of communication with the pupils (the teachers do not explain and do not motivate the mark given), of the threat with a poor mark, of the use of the mark as a means of penalization, of the refusal of any intervention over the made evaluation. Any exterior influence, no matter of what origin, is seen as a forbidden intervention, like a decrease of the teacher's prestige, and the concessions are qualified as harmful moral compromises" (Voiculescu, 2000, p. 182).

The fictitious model of the "perfect" pupil deals with the fact that during the formative process of building up the pupils' moral personality, the teacher is guided by a model of personality which works as a prototype for the way in which the pupils should evolve. This prototype is built either on the "model of his/her own personality or of the ideal one which even the teacher regrets for not being capable to reach, but it can also be a borrowed model, a cliché or simply a 'mosaic' of attributes which the teacher consider necessary, important, positive" (Voiculescu, 2000 , p. 188). The problem which emerges is that this model of personality works only as an abstract prototype, a moral profile of the perfect pupil, which is besides the reach of the concrete reality on the pupils' personality which is built up of the twine between the age and individual particularities, and the models which the pupils have, their family and the community they belong to. Thus, any real manifestation of the child's behaviour can be interpreted as being "abnormal" from the perspective of the ideal, perfect and abstract model. A synthetic characterization of the ideal pupil, as he is described according to this model, is that of the ideal adult. "The portrait of the ideal pupil is, generally speaking, the portrait of the ideal adult, and the evaluation behaviour made by such a portrait is one that ignores or that does not recognize the childhood as an age, as a step in life" (Voiculescu, 2000, p. 189).

Taking into consideration these ethical aspects of the evaluation act, we may formulate some directions of guidance for the teacher that finds himself/herself in educational situations which are at the limit of good and evil (Voiculescu, 2000, pp. 185 - 187):

1. the school evaluation is not a finality in itself, but an educational means through which the teacher guides the process of pupil training - it proves the unjustified moral of those negative effects over the evolution of the pupil's personality, which is due to some teacher's behaviours, although they behave according to the demands for correctness of the evaluation; we may detach some punctual recommendations:

- the evaluation should not be negative unless the case when it cannot be positive (and this happens only in exceptions);

- the evaluation is diagnostic only under the report on the means, but under the report on the goals, it must be hypothetic;

- the evaluation of those who have poor marks and qualifiers, must be limited to the aspects which have imposed the poor marking and they must not be 
generalized or extended in final sentences or judgments at the address of the ensemble of the pupil's personality.

2. the evaluation reflects the teaching - it is a moral-professional norm which foresees that the level of exigency, the criterions of evaluation, the demands expressed by the teacher, must be at least on the same level and with the same sense with those which the teacher applies in the making and self-evaluation of the teaching activity; the strict evaluation of a weak lesson leads to the loss of the educational virtues of exigency, and even to the pupils' perception that the teacher is compensating his / her own failure on their behalves; we may detach some punctual recommendations:

- the teacher does not have the moral right to ask from the pupils, in their activity, qualities which are not first of all present in his/her activity;

- the evaluation of those who have poor marks and qualifiers for the majority of the classes must be seen as reflecting first of all the teacher's activity and only in a secondary plan (and as a consequence) the pupils' activity;

- the merits for the pupils' successes must be attributed by the teacher to the pupils themselves.

3. the pupils' evaluation must be transparent - it is a demand which imposes that the teacher must communicate and explain to the pupils all the data which he/she himself/herself uses in evaluation (what and how must be learned, when and how they will be evaluated, what criteria will be used, etc.); we may detach some punctual recommendations:

- the teacher must respect the pupil's right to know his/her own marks and the reasons why he/she got them;

- the teacher must communicate (make public) out of his/her own initiative or, according to the case, at the pupils' (parents') demand the marks given to all the pupils of a class;

- the teacher must admit that he/she might be wrong, he/she must change a mark or a qualifier initially given if the pupil gives strong arguments for his/her demand and/or if other pupils (which are part of the same class) agree and support these arguments by taking into consideration the evaluation criteria which are accepted.

Among the principles which guide the teacher's activity from the ethic point of view, it is worth to remember: the commitment towards the pupils, the commitment towards the didactic career, towards colleagues, towards the social and school community, principles which are part of the Deontological Code of the Didactic Career.

\subsection{The Hypothesis, Objectives and the Research Methodology}

Starting from these observations, we are trying to make an investigation which should reflect the future teachers' thoughts over the professional deontology. This should contribute to the changing of the perspective over the braking or 
respecting the professional deontology. The hypothesis of this research was: Which are the thoughts of the future teachers from the pre-school and primary education over braking or respecting the professional deontology? The objectives set were: 1. To determine the thoughts of the future teachers over the didactic professional deontology: the deontology of evaluating one's commitment towards one's pupils; 2. To find suggestions, recommendations, proposals and solutions so as to encourage the deontological training of future teachers; 3 . To pin-point the effects resulted from the deontological training of the future teachers by going through the specialty classes and by means of the pedagogical training.

Taking into account that "the focus groups work effectively in determining the points of view, the feelings and the opinions of people towards different problems, produces, services or opportunities" (Krueger, R. A.; Casey, M. A., 2005, p. 29), we have organized the 40 third year old students from "Pre-school and Primary Learning Pedagogy" specialty, into groups of 8 persons. We have also taken into consideration some other criteria: the difference of age between the members of a group should not be bigger than 2 years, and their desire to lean more towards the pre-school learning than the primary one. The problematic studied and discussed in the focus groups was that linked to the commitment towards the pupils and the evaluation deontology such as: using evaluation as a means to push or to discipline, the increased rhythmicity of the formative assessment as a means to obtain a feedback for the teaching- learning activity within a class, the connection between the learning activity taking place at school and the one taking place at home, the permanent preoccupation of the teacher to stimulate the pupils' spirit of investigation, the gain of new knowledge, the understanding and development of one's personal goals, the overuse of the availability of children to learn from an early age reading, writing and arithmetic.

\subsection{Results and discussions}

The most often researched aspect of the commitment towards the pupil is found in the evaluation deontology. "A particular case of the pedagogical deontology, the evaluation deontology deals with the set of values and principles which are essential for the evaluation process: respect, credibility, trust, standardization, objectivity, practicability, validity" (Brăescu, 2009). Besides these moral values and principles, the ethical dimension of the evaluation presupposes a series of moral qualities and of will and character attributes, like diligence or laziness, seriousness or unreliability, discipline or indiscipline, good will or bad will, correctness or incorrectness, and others. All of these can be detached and interpreted by taking into consideration the teachers' value judgments in the evaluation act, because "a 9 or a 10 mark pupil is implicitly not only intelligent, creative, competent, but also hardworking, conscientious, serious, ambitious, etc. In the same way, a 5 mark pupil is considered to be "weak" on what concerns his intellect, but also lazy, unconscientious, unwilling, etc." (Voiculescu, 2000, p. 181). 
In what concerns using evaluation as a means to punish or discipline, all students agreed that is represents a violation of the professional deontology, and approximately $30 \%$ of students have underlines the fact that in the context of the new legislative regulations regarding the status of the didactic staff, whenever a teacher is constrained or exposed to a difficult situation, the use of evaluation in this purpose might be a solution. Some $25 \%$ have suggested that giving more homework (either $\mathrm{t}$ the whole class or to some specific pupils) might contribute to solving this problem and might not allow the building- up of a wrong attitude towards the act of evaluation. The rest of the students have stated that evaluation must reflect the training and the knowledge, abilities and competencies acquiring level of each pupil, without building a distorted and wrong attitude towards the act of evaluation.

On what concerns the increased rhythmicity of the formative evaluation, seen as a means to obtain a feedback for the teaching-learning activities taking place in a classroom, $50 \%$ of the students agreed to use the individual tests in order to correct in due time some learning problems which might arise regarding some topics like: multiplication, division, parts of speaking, etc.. While the other 50\% have pin-pointed the stressful effect of these evaluations because not all pupils may handle this accelerated rhythm of learning and cannot sustain the same effort to continuously learn, thus resulting the chronic fatigue, overworking and the negative attitude towards school.

The commitment towards pupils is a principle with a big philosophical load, because according to it, "the teacher is always trying to help the pupils with whom he/she is working to develop their potential, for a complete integration in the school and social life. In this sense, he/she is always preoccupied with the stimulation of the pupils' wish for more information, with the encouragement for the obtaining of new knowledge, with the understanding and the developing of personal goals on a long and short term"(see The Deontological Code of the Pedagogical Profession). We can feel the influence of the Kantian principle of autonomy, which foresees that "all the rational beings are submitted to the law according to which each and every person should never treat their person and that of the others only as a means, but also as an end in itself' (Kant, 1995, p. 242). Thus, all students have stated that the teacher must give to the pupil the liberty to formulate and present his/her own opinions, to act independently in the process of learning, to skim through or to frequent different disciplines, programmes of study, which will allow his/her individual progress, according to their personal interests, without restricting the access to them and without making any kind of discrimination of no matter what origin (race, religion, sex, age, people, political views, social status, etc.). In this sense, the idea of impartiality which stands at the base of all theories about morality, foresees that "the interests of all individuals are important: from the moral point of view there are no privileged persons"; the lives of all have the same value" (Rachels, 2000, p. 17). This would mean that for the teacher, all the pupils have the same importance, the welfare of every pupil is very 
important for him/her. This demand of impartiality refers, at the same time, to the exclusion of any scheme "which treats the members of some disadvantaged groups as being somewhat inferior from the moral point of view" (Rachels, 2000, p. 17) for example the children that are part of a religious or ethnic minority, or those that come from poor social surroundings, from the working class or from "the hood". The teacher's moral judgments should be sustained on good grounds to avoid the pupils' discrimination in the process of education. In this way, the demand of impartiality should function as a rule which forbids the teachers to treat a pupil differently from another, if he/she does not have solid reasons to do so - for example the positive discrimination (special classes or places for the gipsy children) - giving, at the same time, equal value to every pupil's interests, in his/her effort to guide the pupils' moral behaviour. Respecting this criterion of impartiality, means that in his/her relationships with the pupils, the teacher must always think at them "as to a finality, not as to a means" (Kant, 1995, p. 237). Thus, from this perspective, the pupils are the finality of the teacher's educational activity, which presupposes that the teacher's duty towards the pupils must be to promote their welfare, the observance of their rights, in avoiding any harm done to them, generally, into the achievement of their goals (Rachels, 2000, p. 127).

Another aspect of the commitment towards the pupil takes into account the age particularities and the learning specific of that age. The tendency to give more information, to work and practice more out of the desire to train and develop the abilities described in the school curriculum, the tendency to diversify the activities and to peruse even the extended curriculum, the large homework volume, leads towards braking the professional deontology. Thus, the pupil becomes simply a means because his overload in the learning process, be it formal or informal, leads to the teacher's satisfaction that he/she has succeeded into perusing the curriculum. Here we are talking about the quantity of the learning process and not its quality, because the pupil's welfare and rights are broken. The overloading of pupils' ability to learn from an early age, reading, writing and arithmetic by decreasing the period of direct knowledge and by moving faster towards an abstract approach of the teaching-learning activities, will make pupils and teachers alike to ask themselves if this really means to be committed toward one's pupils or if it simply means to "steal" their childhood.

\section{Conclusions}

Synthesizing all these ethical aspects of the didactic career, we may notice the importance and the necessity of reporting to the Deontological Code of the Teacher's Profession, which on one hand must guide the behaviour of those who, being in a position which offers them power and influence, could produce, with or without intention, even negative effects over the evolution of those who were given to them to be trained - more precisely, the goal of such a moral code is to protect 
the pupil from the excesses or the negative effects of the teacher's power -, and on the other hand, to protect the professional people from possible plaints and reproaches which might be brought to them in the cases of some failures, even though these did not took place because of the deviation from the norms of professional ethic, or the professional was found in some social and educational contexts situated at the limit between right and wrong (Voiculescu, 2000, p. 187). In conclusion, we may say that the teacher is the main factor of responsibility in education. "The teacher's ethical responsibilities, beyond reporting to a general set of rules and codes, mean the ability to find suitable solutions for particular situations, to display behaviours that are consistent with the beliefs of the achiever and to live the moral values, not just to declare them" (Jeder, 2013, p. 436).

As a measure to increase the quality of education, it is imposed, in the initial training of the didactic staff, to give a special importance even from the perspective of the pedagogical deontology to their qualification, with the mention that the simple knowing of the Deontological Code of the Teacher's Profession does not lead to the conclusion that the future teachers will have a behaviour in concordance with it. The simulation of some closer cases to school's reality in which the future teachers will have to take decisions using these norms of professional ethics, during the training activities, would lead to the acceptance and to the learning of these, giving to the future teacher a minimal experience which should help him to integrate easily in the real school life.

\section{REFERENCES}

Brăescu, V.-S. (2009). Elemente de deontologie a evaluării în contextul creşterii calității actului educațional,

http://educatiaadultilor.blogspot.com/2009/01/elemente-de-deontologie-evaluariin.html

Dumitru, I. Al. (2007). Formarea personalului didactic - între deziderat şi realitate. In Dumitru, I. Al. (coord.), Calitatea formării personalului didactic. Timişoara: Ed. Mirton.

Jeder, D. (2013). Teachers' Ethic Responsibilities in the Practice of Education and Training. Procedia - Social and Behavioral Sciences 92(2013), 432 - 436, www.sciencedirect.com

Kant, Im. (1995). Întemeierea metafizicii moravurilor. In Kant, Im., (1995). Critica ratiunii practice. Bucureşti: Ed. IRI.

Krueger, R. A., Casey, M. A. (2005). Metoda focus grup: ghid practic pentru cercetarea aplicată. Iaşi: Editura Polirom.

Marin, S. (2013). Politici şi strategii de formare a resursei umane din educaţie. Bucureşti: Editura Didactică şi Pedagogică.

Rachels, J. (2000). Introducere în etică. Bucureşti: Ed. Punct. 
Voicu, A. V., Levi, A. (2003). Necesitatea abordarii problematicii integrarii sociale a excelentului în sport din perspectiva unei pedagogii juridice de domeniu. Revista Stiinţa sportului.

Voiculescu, E. (2000). Evaluarea şcolară şi deontologia profesiunii didactice. In Ionescu, M., Chiş, V., (coord.), Studii de pedagogie. Omagiu profesorului Dumitru Salade. Cluj-Napoca: Ed. Presa Universitară Clujeană. 